\title{
Regulatory Threats to the Law Degree: The Solicitors Qualifying Examination and the Purpose of Law Schools
}

\author{
Richard Bowyer ${ }^{1}$ \\ Published online: 4 May 2019 \\ (c) The Author(s) 2019
}

\begin{abstract}
Two major regulatory changes are affecting the provision of undergraduate legal education in England and Wales. On the one hand, the Qualifying Law Degree is being deregulated, meaning law schools are free to make significant changes to how and what they teach. On the other hand, higher education in England has seen a significant overhaul through the creation of the Office for Students, which treats students as consumers. Now more than ever, law schools need to ask themselves existential questions which will not only test their continued relevance or indeed viability within the 'market' for higher education, but also the status of the discipline of law as a whole. The regulatory landscape may indeed present a significant threat, but it is also an opportunity to reflect on what law schools are for, and consequently what changes could result from the academic freedom that comes with deregulation. Whilst different law schools will interpret their mission differently, they should caution against either generalised inertia or succumbing to an outcomes-oriented provision that simply prepares students for the new Solicitors Qualifying Examination. Instead, law schools will find their proper purpose in critical reflection and academic self-grounding, providing undergraduate students with a 'question everything' mentality, and showing them that law is something to be experienced and not merely learnt.
\end{abstract}

Keywords Academic freedom - Critique $\cdot$ Law degree $\cdot$ Legal education - Office for Students $\cdot$ Solicitors Regulation Authority $\cdot$ Universities

With the anticipated arrival of the Solicitors Regulation Authority's (SRA) new centralised exams for qualification of a solicitor in England and Wales, we are again forced to address the question: what are universities (or law schools) for? Unless law schools take charge of this question themselves, the answer will be derived from governmental or regulatory norms concerned with value for money, employment

Richard Bowyer

R.A.Bowyer@exeter.ac.uk

1 Law School, University of Exeter, Exeter EX4 4RJ, UK 
outcomes, and consumer rights. Law schools in England sit between two regulators which are part of the same neoliberal apparatus that is reducing everyone to the status of a consumer. The SRA, on the one hand, has ceased to participate in the regulation of legal education as learning, and focused instead on administering their own exams assessing outcomes-all in the name of protecting the consumer of legal services (SRA 2015). The Office for Students (OfS), on the other hand, renders students themselves as consumers by adopting the Competition and Markets Authority (CMA) approach to Higher Education as a service rendered (OfS 2018). Any government-identified socially useful public good associated with universities or law degrees - such as widening participation or fair access - is added on top: the surplus value of running the marketised university. If law schools succumb to these regulatory norms, they will become training suites for the SRA's exams, producing tomorrow's 'minimally competent' solicitors whose salaries will be tracked by Her Majesty's Revenue and Customs for several years after graduation, to ensure that the public cost of administering the loan book has provided the taxpayer-consumer with value for money. ${ }^{1}$ Law schools must take charge of the question of their rightful purpose, if they are to avoid their reduction to marketised utility.

As John Donne almost said, no regulator is an island. The SRA, however, has a different view. They have construed their own purpose extremely narrowly by thinking that the best way of protecting consumers of legal services is to assess entry standards of would-be solicitors for themselves. The Solicitors Qualifying Examination (SQE) will use multiple choice tests, legal research and writing skills assessments, and practical skills assessments to determine minimal competency. The overall cost of the exams will be in the range of $£ 3000-£ 4500$, and therefore promises to be much less than the current cost of a Legal Practice Course (SRA 2018). By not regulating the degree education required for entry to the profession (entrants can have any degree or equivalent Level 6 or 7 qualification or apprenticeship), the SRA expects a whole range of degree and non-degree education courses to feed into the SQE. Data on provider success rates for the SQE will be published, encouraging or incentivising SQE alignment for many current providers of law degrees. Now that the OfS has realised that it too is an island, it has publicly stated that it will let failing universities fail, which is precisely the opposite function of its predecessor organisation, Higher Education Funding Council for England (HEFCE), which was the university's fund of last resort.

The 'market' for legal education will become increasingly stratified as a consequence of these regulatory initiatives. Some law schools will see themselves as untouchable, and will go on maintaining their place in the economy of producing the next crop of law firm partners. The SQE is, of course, a necessary qualifying step, but employers will still want to know how you qualified, or more simply where you studied. Other law schools will need to decide whether they align to SQE, or do something else. Whatever the specific response to the SQE, law schools should

\footnotetext{
${ }^{1}$ Longitudinal Education Outcomes (LEO) links earnings data held by the tax office to the university and course attended by those taxpayer/graduates. The Teaching Excellence Framework and the OfS use this metric to assess the performance of higher education providers.
} 
ensure they protect, nurture and develop what law schools are for, which must not be understood in the terms given to them by the pincer claws of our two regulators. A reduction of the law school to the requirements of its professional regulatory body would leave it open to future irrelevance or obsolescence. As Derrida warned: 'Beware of what opens the university to the outside... but also of what, closing in on itself, would create only an illusion of closure, would make the university available to any sort of interest, or else render it perfectly useless' (Derrida 2004, p. 153).

It is perhaps easier to say what universities should not be for, than to establish a stable sense of origins and ends. We might resolve that universities (or law schools) should not be about meeting a market demand for solicitors, and that our saying so would be an act of our academic freedom or autonomy, as if freedom was the point of universities. This freedom is a freedom for disciplines to govern themselves. However, Judith Butler's (2009) defence of academic freedom, including 'academic self-governance', identifies an enigma. Academic departments enjoying freedom over their own governance and curricula choices are maintaining those choices according to disciplinary norms and practices. But in whose interests are those norms maintained? If established disciplinary norms give validity to current and future practices, 'we establish a conservative academic culture and even suppress disciplinary innovation' (Butler 2009, p. 774). If we defend our position in the face of external regulatory pressure, then Butler reminds us that we must do better in articulating what grounds our academic freedom.

Butler's response is to commit ourselves to critique. Drawing on Foucault and others, Butler explains that the task is to ensure that we do not become 'ungovernable for all time', but rather that we resist being 'governed in this or that way' (2009, p. 791). Rather than critique as 'nay-saying' or 'nihilism', it is about critique as 'that revolution at the level of procedure without which we cannot secure rights of dissent and processes of legitimation' (2009, p. 795). It is dissent, in the face of processes of governmentality, or in the foreclosure of what is possible, that provides this necessary procedural right which is also a form of self-grounding for the freedoms that establish our position as academics, disciplines and the university. In her reading of Antigone (and Lacan), Butler further explained her turn to origins or grounds. Rather than seeing Antigone as fatalistic, she represented something else: communicability that recalls the origin upon which society (or kinship) is based, before the 'hasty foreclosures' of the state (Butler 2000, p. 55). Butler's turn to origins-which we follow here as we find the grounds of academic freedom-is something which is open-textured about what is possible, not what is merely given or received. In short: the origins can be changed. The university (and the law school) must rediscover its origins in the face of these new external threats that are seeking to steer universities towards an outcomes-based, ends-oriented education.

We have now established that universities are grounded, albeit in a self-grounding sort of way. They are, at most, procedurally grounded. Universities are essentially about the processes of critique, and cannot be reduced to, or in the exclusive service of, professional norms and practices that exist outside the university.

Adopting a critical standpoint in relation to the external regulatory environment does not mean that the discipline of law is immune from revaluation or changebut that change should come from within. We can recall Butler's earlier point that 
maintaining disciplines according to disciplinary norms would be an inherently conservative practice because the discipline would authorise itself according to existing or long-standing norms and practices in an uncritical sort of way. If we are adopting a critical position in relation to our regulators, then we should be prepared to do likewise with our own discipline too.

Law, like many of the other disciplines, is something which does indeed have a life outside of the university campus. And the discipline of law has regularly reinvented itself in response to the inside/outside of law's being. Notable examples have included the approach of the legal realists, critical race theory, critical legal studies, and legal feminism - all of which emerged out of a critical response to law in its more dogmatic forms. There is also a growing practice of 'law and...', as we undertake interdisciplinary approaches and methods in order to see law from a different vantage point, or to produce cross-disciplinary affects. Law schools have indeed taken a critical stand in relation to the established or dogmatic forms of law, but these enterprises have been mostly felt in our research or in our postgraduate teaching. Now that the undergraduate law degree is being fully deregulated-at least as far as the SRA is concerned-would it not be a great opportunity to radically reform our undergraduate law curricula, in defence of our discipline and in spite of the regulatory environment?

The striking thing about most undergraduate law programmes in England is how similar many of them are. Most, but not all, law schools approach law primarily through a content-based view of the subject. Because of the way the law degree has been regulated, this typically follows a pattern of just over half of the degree comprising 'core' modules specified by the SRA and the Bar Standards Board (BSB), and a range of options normally featuring towards the latter stages of the degree. Closed-book exams are a very common form of assessment, although they are no longer formally required by the SRA or BSB. Some variation exists, particularly in respect of how the subject of law is approached: 'black-letter' or doctrinal approaches could be contrasted with socio-legal and 'law in context' approaches. But otherwise most law degrees try to do very similar things in very similar ways, of course with some exceptions.

One of the better things that could come out of this coming regulatory environment is for law schools to bring their practices of critique to the undergraduate curriculum. Doing law could now mean a whole host of things other than doctrinal learning. Indeed, it must mean more than simply learning the law, as otherwise the university law degree would be undercut by other private providers of SQE 'cramming' courses. The thing which has been neglected under the SRA/BSB 'qualifying law degree' has been the experience of law: activism, resistance, law clinic activities. Law degrees could be a site of radical critique, of a 'question everything' mentality, with activism, dissent and practice at its heart. Students can bring critique to law, and become something far more than the minimally competent solicitors envisaged by the SRA's exams.

Law schools will now be free to teach as they wish. Freedom is a heavy responsibility. Some law schools will do nothing (or next to nothing) out of fear of change, generalised inertia, or because the regulator continues on as some sort of internalised superego. To paraphrase Freud, the SRA may be stronger in its absence. Others 
will want to keep aligned with the BSB anyway, as a mark of quality or the perception of rigour. There will be a section of the market for law schools that will have no choice but to do something towards the SQE direction, because they are already struggling with student numbers following the abolition of student number caps that came with $£ 9000$ fees. Whatever law schools do, it is important that they keep some of their identity as a university discipline, so they do not fold into the regulatory abyss, where they could very quickly become irrelevant.

Open Access This article is distributed under the terms of the Creative Commons Attribution 4.0 International License (http://creativecommons.org/licenses/by/4.0/), which permits unrestricted use, distribution, and reproduction in any medium, provided you give appropriate credit to the original author(s) and the source, provide a link to the Creative Commons license, and indicate if changes were made.

\section{References}

Butler, Judith. 2000. Antigone's claim: Kinship between life and death. New York: Columbia University Press.

Butler, Judith. 2009. Critique, dissent, disciplinarity. Critical Inquiry 35: 773-795.

Derrida, Jacques. 2004. Eyes of the university (trans: Jan Plug et al.). Stanford: Stanford University Press. Office for Students (OfS). 2018. Securing student success: Regulatory framework for higher education in England. https://www.officeforstudents.org.uk/media/1406/ofs2018_01.pdf. Accessed 3 Feb 2019.

Solicitors Regulation Authority (SRA). 2015. Training for tomorrow: Assessing competence. https:// www.sra.org.uk/documents/SRA/consultations/t4t-sqa-consultation.pdf. Accessed 3 Feb 2019.

Solicitors Regulation Authority (SRA). 2018. SQE to be introduced in Autumn 2021. https://www.sra. org.uk/sra/news/press/sqe-launch-2021.page. Accessed 3 Fe 2019.

Publisher's Note Springer Nature remains neutral with regard to jurisdictional claims in published maps and institutional affiliations. 